\title{
Production of Monozygotic Twins by Splitting of 2-cell Stage Embryos in Mice
}

\author{
Mamoru Togashi, Hiroshi Suzuki, Tatsuya Miyai \\ and Michio T. Окамото \\ Research Laboratories, Chugai Pharmaceutical Co., Ltd., \\ No. 41-8, 3-chome, Takada, Toshima-ku, Tokyo 171
}

(Accepted for publication February 2, 1987)

Summary. The purpose of present study was to examine the ability of potential development of splitted mouse embryos at $2-(1 / 2)$ and 4-cell $(2 / 4)$ stage.

Two and 4-cell embryos were collected from the superovulated $\mathrm{F}_{1}(\mathrm{C} 57 \mathrm{BL} / 6 \mathrm{~J} \times$ $\mathrm{C} 3 \mathrm{H} / \mathrm{HeN}$ ) mice $48 \mathrm{hr}$ after hCG injection. After removal of zona pellucida (Hank's solution $+0.5 \%$ pronase), the embryos were separated into two halves by pipetting in $\mathrm{Ca}^{2+}$ or $\mathrm{Ca}^{2+}$. $\mathrm{Mg}^{2+}$-free BMOC-3 medium containing $0.02 \%$ EDTA. Splitted embryos were cultured in BMOC-3 medium in Multiplate Terasaki for 48, 72 or $96 \mathrm{hr}$. Then the embryos developed into blastocysts were transferred to recipients on Day 2 or Day 3 of pseudopregnancy. These recipients were killed at Day 17 of gestation and the existence live fetuses, dead fetuses and swellings were examined. Furthermore, a monozygotic pair of $1 / 2$ embryos developed into blastocysts after $48 \mathrm{hr}$ culture were transferred to recipients on Day 2 of pseudopregnancy or pregnancy.

The results were as follows:

1) Success rate of splitting 2- and 4-cell embryos by pipetting were $93.5-100 \%$ and $88.2 \%$, respectively.

2) Most of $1 / 2$ and $2 / 4$ embryos were developed into blastocysts after $72 \mathrm{hr}$ culture $(93.9-100 \%)$.

3) The propotion of live fetuses after transfer of $1 / 2$ embryos were $14 / 56(25.0 \%)$, $4 / 52$ (7.7), $12 / 60(20.0)$ and $3 / 74$ (4.1), and those of 2/4 embryos were 14/49 (28.6), $12 / 57$ (21.2), $11 / 57(19.3)$ and $3 / 43(7.0)$ in the case of $48 \mathrm{hr} \rightarrow$ Day $2,72 \mathrm{hr} \rightarrow$ Day 2, $72 \mathrm{hr} \rightarrow$ Day 3 and $96 \mathrm{hr} \rightarrow$ Day 3 combinations, respectively.

4) One or six sets of monozygotic twins were obtained after transfer of a pair of splitted embryos into pseudopregnant or pregnant recipients.

These results indicate that the zona pellucida is not necessary for the development of embryos in vitro and it is possible to produce monozygotic twins from 2-cell stage embryos. KEY WORDS; MOUSE, MONOZYGOTIC TWIN, 2-CELL EMBRYO, SPLITTING.

Jpn J Anim Reprod 33, 51-57, 1987

マウスの 2 細胞期胚分離による一卵性双生仔の作出

富樫守・鈴木 宏志・宮井 達也・岡本 道生 中外製薬株式会社開発研究所 171 東京都豊島区高田3-41-8

一卵性双生仔は全く同一の遺伝子組成を持つと考兄ら その人為的作出は単に子の数を倍増できるだけでなく遺 れることから, 動物実験において遺伝因子と環境因子の 伝的統御が困難な動物種においては, 短期間に同一の遺 影響を解析可能とする極めて有用な動物である。また，伝子組成を持つ複数の個体が得られるために質の高い動 
物実験を可能とし，その利用価值は非常に高いと考えら れる。

このようなことから近年, 初期胚の分離ならびに切断 によって一卵性双生仔や多生仔を作出する試みが盛んに 行なわれるようになり, 胚分離法によってマウス（Tsunoda and McLaren, 1983), ヒッジ (Willadsen, 1979, 1980)、ヤギ（角田ら，1984）, ウシ (Willadsen et al., 1981）でそれぞれ一卵性双生仔が作出されている。さら にヒッジ (Willadsen, 1981) およびゥシ (Willadsen and Polge，1981）では 4 個に分離した割球から一卵性 三つ仔の作出も報告されている。しかしながら，こうし た一連の実験は胚を分離してそれぞれの割球を空の透明 帯へ帰納, 寒天による包埋, さらには同種あるいは異種 動物の卵管内で一定期間培養後, 受卵雌へ移植するなど の高度な技術と繁雑な操作を必要とするものである。

そこで本実験では, 簡便かつ効率的な一卵性双生仔の 作出法を確立する目的で, マウスの 2 および 4 細胞期胚 を対象に, 操作が簡単なピペッティング法による肧分離 を試み, その後の体外での肧発生と産仔への発生能力に ついて検討したので報告する。

\section{材料と方法}

供試動物および飼育条件 実験には当研究所で維持繁 殖している F1（C57BL/6J $\times$ C $3 \mathrm{H} / \mathrm{HeN})$ および IV CS 系マウスの成熟未経産雌ならびに同系統の成熟雄を用い た。供試動物は温度 $24 \pm 2^{\circ} \mathrm{C}$, 湿度 $50-60 \%$, 換気回数 12-15回 $/ \mathrm{hr}$ ，照明時間14時間 (5:00 19:00) の動物 室内で飼育され, 固型飼料 (CA-1, 日本クレア) と水 を自由摂取させた。

胚の回収 F1 雌マウスに性周期とは無関係に48時間 間隔で PMSG（セロトロピン，帝国臓器）および hCG （プベローゲン，三共ゾーキ）を各 $5 \mathrm{IU}$ 皮下投与して過 排卵誘起を行なった。 hCG 投与後直ちに F1 成熟雄と 一晚同居させ, 翌朝㓐栓の確認された個体を妊娠成立と みなし，この日を妊娠 0 日（Day 0) とした。hCG 投与 後約48時間にと殺開腹して卵管を取り出し, 直ちに流 動パラフィンで覆われたペトリ皿内の BMOC-3 培地 (Brinster, 1971) に移し，卵管灌流法により 2 および 4 細胞期胚を回収した。

胚の分離および培養 回収された胚は $0.5 \%$ プロナー ゼ（アクチナーゼ，科研製薬）を含む Hank's 液内で透 明帯を除去しだ。その後, 肧は流動パラフィンで覆わ れたテラサキマルチプレート（住友ベークライト）内の $0.02 \% \mathrm{EDTA}$ を含む $\mathrm{Ca}^{2+}$ または $\mathrm{Ca}^{2+} \cdot \mathrm{Mg}^{2+}$-free
BMOC-3 培地 (Fiser and Macpherson, 1976) 内に移 し，10分以内または10--30分間インキュベートした。肧 の分離はマイクロインジェクターあるいはマウスピース に接続したガラス毛細管ピペットを用いて，吸引・排出 を繰り返すことにより行なった。2 分離された泼（2 細 胞期胚胚 : $1 / 2$ 肧, 4 細胞期胚 : $2 / 4$ 胚）はテラサキマル チプレートの同一 well 内に一対ずつ入れ, BMOC-3 培 地内で72時間まで培着 $\left(5 \% \mathrm{CO}_{2}, 95 \%\right.$ air $)$ 乙, 胚盤 胞への発生を観察した。

分離胚の移植 移植には $0.02 \% \mathrm{EDTA}$ を含む $\mathrm{Ca}^{2+}$. $\mathrm{Mg}^{2+}$-free BMOC-3 培地内で10-30分間インキュベー 卜後 2 分離した $1 / 2$ および $2 / 4$ 胚を用いた。泼は 48,72 および96時間培養で胚盤胞へ発生したものを, 精管結紮 雄（IV CS 系）との交尾により偽妊娠を誘起した IV CS 系受容雌の Day 2 または Day 3 亿子宮角一側当り 47 個ずつ移植した（以下，例えば48時間培養した胚を Day 2 の受容雌に移植した場合は48時間 $\rightarrow$ Day 2 と略 す)。受容雌は Day 17 亿殺開腹して着床数, 生存胎 仔数および死亡胎仔数を調べた。

さらに一卵性双生仔の作出にあたっては，上述と同一 条件で分離した $1 / 2$ 肧を 48 時間培養した後, 双方の泼が 肧盤哭一発生したものをDay 2 の偽妊娠あるいは妊娠 受容雌の子宮角に一対のみ移植し分婏させた。

\section{結果}

肧の分離および培養成績 透明帯除去 2 および 4 細胞 期胚のピペッティングによる 2 分離成功率を Table 1 に 示した。 2 細胞期胚の分離操作では, 分離用培地あるい は処理時間にかかわらず 93.5-100\% の成功率でほとん ぞの肧を分離することができた。一方，4 細胞期胚では $\mathrm{Ca}^{2+} \cdot \mathrm{Mg}^{2+}$-free BMOC-3 培地内で10-30分間インキュ ベートすることにより $88.2 \%$ の肧を 2 割球ずつに分離 することができた。

次に，分離胚を 48 および72時間培養した時の胚盤胞へ の発生率を Table 2 と示した。1/2 肧では培養48時間で 67.6-86.8\%，72時間では 95.5-100\% の肧が肧盤胞へ と発生した（Fig. 1)。一方，2/4 胚では培養48時間で分 離肧すべてが胚盤胞へと発生した。また，72時間培養で 分離胚が双方とも肧盤胞へ発生した割合は， $1 / 2$ 胚で 93.9-100\%，2/4 胚で 100\% であり，胚盤胞への 発生 が分離胚の一方のみであった例は注とんどみられなかっ た。

分離肧の移植成績 $48,72 お$ よび96時間の培養で肧盤 胞へ発生した $1 / 2$ および $2 / 4$ 肧を Day 2 あるいは Day 

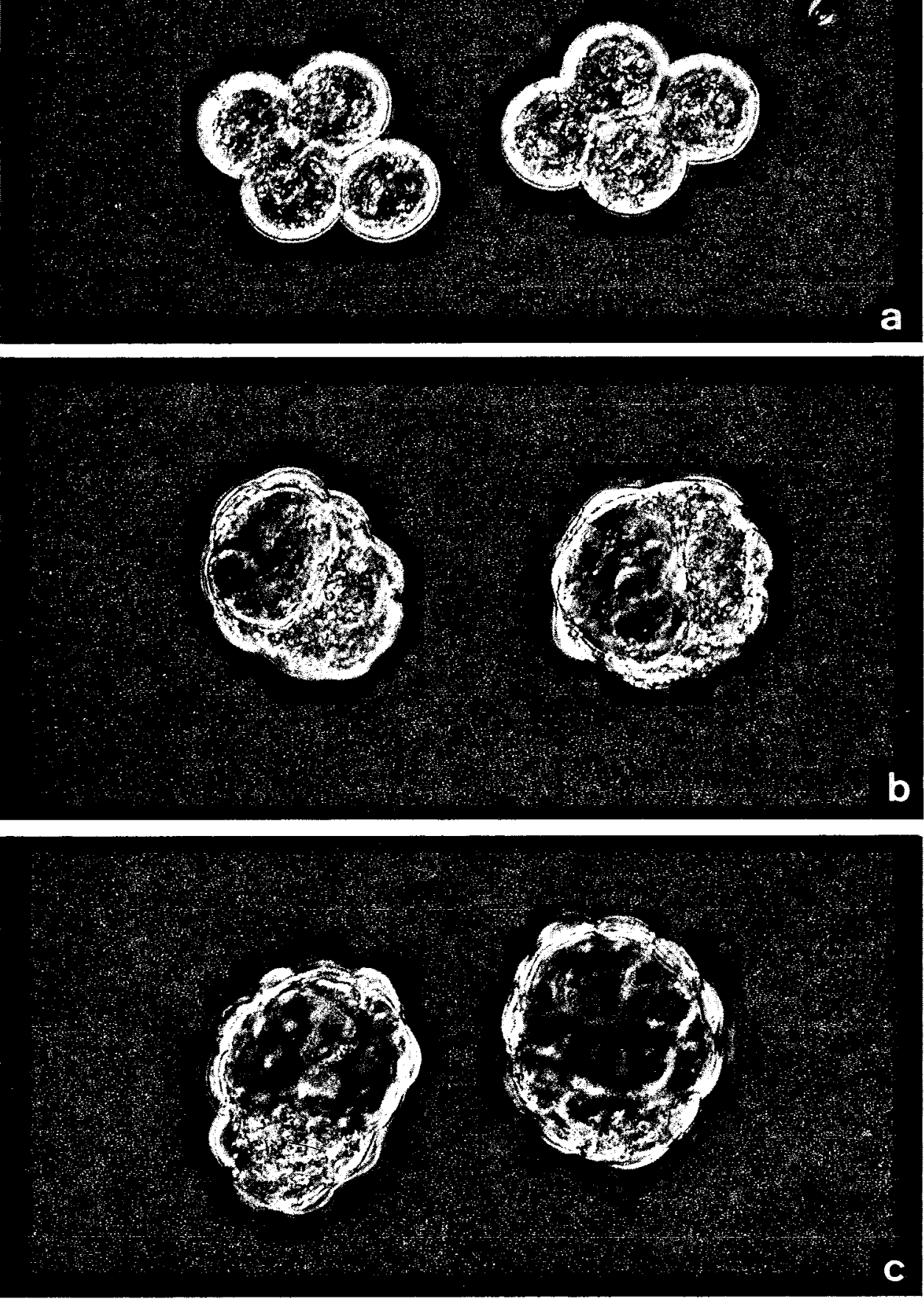

Fig. 1. In vitro development of the monozygotic pair splitted from 2-cell stage mouse embryo, after 24 (a), 48 (b) and $72 \mathrm{hr}$ (c) in culture. 
Table 1. Success rate of splitting 2- and 4-cell stage mouse embryos by pipetting

\begin{tabular}{llccr}
\hline \hline $\begin{array}{c}\text { Stage of } \\
\text { embryos }\end{array}$ & $\begin{array}{c}\text { Medium for } \\
\text { separation* }\end{array}$ & $\begin{array}{c}\text { Duration of } \\
\text { treatment** }\end{array}$ & $\begin{array}{c}\text { No. of } \\
\text { embryos }\end{array}$ & $\begin{array}{c}\text { No. of } \\
\text { embryos splitted } \\
(\%)\end{array}$ \\
\hline \multirow{2}{*}{2 -cell } & $\mathrm{Ca}^{2+}$-free & -10 & 31 & $29(93.5)$ \\
& & $10-30$ & 33 & $33(100)$ \\
\hline 4-cell & $\mathrm{Ca}^{2+} \cdot \mathrm{Mg}^{2+}$-free & $10-30$ & 19 & $19(100)$ \\
\hline $\mathrm{Ca}^{2+} \cdot \mathrm{Mg}^{2+}$-free & $10-30$ & 119 & $119(88.2)$ \\
\hline
\end{tabular}

* Embryos were separated in $\mathrm{Ca}^{2+}$ or $\mathrm{Ca}^{2+} \cdot \mathrm{Mg}^{2+}$-free BMOC-3 medium containing 0. 02\% EDTA.

** Minutes.

Table 2. In vitro development of the mouse embryos splitted by pipetting at 2- and 4-cell stage

\begin{tabular}{|c|c|c|c|c|c|c|}
\hline \multirow{2}{*}{$\begin{array}{l}\text { Type of } \\
\text { embryo } \\
\text { splitted }\end{array}$} & \multirow{2}{*}{$\begin{array}{l}\text { Medium for } \\
\text { separation* }\end{array}$} & \multirow[t]{2}{*}{$\begin{array}{l}\text { Duration of } \\
\text { treatment*** }\end{array}$} & \multirow{2}{*}{$\begin{array}{l}\text { No. of } \\
\text { pairs/ } \\
\text { No. of } \\
\text { embryos } \\
\text { cultured }\end{array}$} & \multicolumn{2}{|c|}{$\begin{array}{c}\text { No. of embryos developed } \\
\text { to blastocyst } \\
(\%)\end{array}$} & \multirow{2}{*}{$\begin{array}{l}\text { No. of pairs } \\
\text { developed to } \\
\text { blastocyst } \\
\text { for } \\
72 \mathrm{hr} * * *\end{array}$} \\
\hline & & & & $48 \mathrm{hr} * * *$ & $72 \mathrm{hr} * * *$ & \\
\hline \multirow{2}{*}{$1 / 2$} & $\mathrm{Ca}^{2+}-$ free & $\begin{array}{r}-10 \\
10-30\end{array}$ & $\begin{array}{l}29 / 58 \\
33 / 66\end{array}$ & $\begin{array}{l}48(82.8) \\
54(81.8)\end{array}$ & $\begin{array}{l}57(98.3) \\
63(95.5)\end{array}$ & $\begin{array}{l}28(96.6) \\
31(93.9)\end{array}$ \\
\hline & $\mathrm{Ca}^{2+} \cdot \mathrm{Mg}^{2+}$-tree & $\begin{array}{r}-10 \\
10-30\end{array}$ & $\begin{array}{l}19 / 38 \\
34 / 68\end{array}$ & $\begin{array}{l}33(86.8) \\
46(67.6)\end{array}$ & $\begin{array}{l}38(100) \\
66(97.1)\end{array}$ & $\begin{array}{l}19(100) \\
32(94.1)\end{array}$ \\
\hline $2 / 4$ & $\mathrm{Ca}^{2+} \cdot \mathrm{Mg}^{2+}-$ free & $10-30$ & $12 / 24$ & $24(100)$ & $24(100)$ & $12(100)$ \\
\hline
\end{tabular}

* Embryos were separated in $\mathrm{Ca}^{2+}$ or $\mathrm{Ca}^{2+} \cdot \mathrm{Mg}^{2+}$-free $\mathrm{BMOC}-3$ medium containing 0. 02\% EDTA.

** Minutes. *** Cultivation time.

Table 3. Results of transfer of the mouse embryos splitted at 2- and 4-cell stage

\begin{tabular}{cccccccc}
$\begin{array}{c}\text { Type of } \\
\text { embryo } \\
\text { splitted }\end{array}$ & $\begin{array}{c}\text { Cultiva- } \\
\text { tion } \\
\text { time* }\end{array}$ & $\begin{array}{c}\text { Day of } \\
\text { pseudo- } \\
\text { pregnancy** }\end{array}$ & $\begin{array}{c}\text { No. of } \\
\text { pregnants/ } \\
\text { No. of } \\
\text { recipients }\end{array}$ & $\begin{array}{c}\text { No. of } \\
\text { embryos } \\
\text { trans- } \\
\text { ferred }\end{array}$ & $\begin{array}{c}\text { No. of } \\
\text { implantation } \\
\text { sites } \\
(\%)\end{array}$ & $\begin{array}{c}\text { No. of } \\
\text { dead } \\
\text { fetuses } \\
(\%)\end{array}$ & $\begin{array}{c}\text { No. of } \\
\text { live } \\
\text { fetuses } \\
(\%)\end{array}$ \\
\hline \multirow{2}{*}{$1 / 2$} & 48 & 2 & $3 / 5$ & 56 & $17(30.4)$ & 0 & $14(25.0)$ \\
& 72 & 2 & $3 / 5$ & 52 & $15(28.8)$ & $4(7.7)$ & $4(7.7)$ \\
& 72 & 3 & $4 / 5$ & 60 & $22(36.7)$ & 0 & $12(20.0)$ \\
& 96 & 3 & $2 / 7$ & 74 & $11(14.9)$ & $2(2.7)$ & $3(4.1)$ \\
\hline \multirow{2}{*}{$2 / 4$} & 48 & 2 & $5 / 5$ & 49 & $30(61.2)$ & $4(8.2)$ & $14(28.6)$ \\
& 72 & 2 & $4 / 5$ & 57 & $22(38.6)$ & $1(1,8)$ & $12(21.2)$ \\
& 72 & 3 & $3 / 5$ & 57 & $16(28.1)$ & 0 & $11(19.3)$ \\
& 96 & 3 & $3 / 4$ & 43 & $8(18.6)$ & 0 & $3(7.0)$ \\
\hline
\end{tabular}

* Hours. $\quad * *$ Recipient were autopsied on Day 17 of pregnancy.

Table 4. Results of transfer of the monozygotic mouse embryos splitted at 2-cell stage

\begin{tabular}{lccccc}
\hline Recipients* & $\begin{array}{c}\text { No. of } \\
\text { recipients }\end{array}$ & $\begin{array}{c}\text { No. of pairs/ } \\
\text { No. of } \\
\text { embryos } \\
\text { transferred** }\end{array}$ & $\begin{array}{c}\text { No. of } \\
\text { recipients } \\
\text { delivered } \\
(\%)\end{array}$ & $\begin{array}{c}\text { No. of } \\
\text { pups } \\
(\%)\end{array}$ & $\begin{array}{c}\text { No. of pairs of } \\
\text { monozygotic } \\
\text { twins } \\
(\%)\end{array}$ \\
\hline Pseudopregnancy & 26 & $26 / 52$ & $7(26.9)$ & $5(9.6)$ & $1(3.8)$ \\
Pregnancy & 27 & $27 / 54$ & $16(59.3)$ & $22(40.7)$ & $6(22.2)$ \\
\hline
\end{tabular}

* Embryos were transferred to the recipients on Day 2 of pseudopregnancy or pregnancy.

** Embryos were cultured for $48 \mathrm{hr}$ after split. 
3 の偽妊娠雌の子宮角に移植した結果を Table 3 に示 した。すなわち48時間 $\rightarrow$ Day 2, 72時間 $\rightarrow$ Day 2, 72時間 $\rightarrow$ Day 3 および96時間 $\rightarrow$ Day 3 の組合わせにおける着 㦿率（着床胚数/移植肧数）は， $1 / 2$ 肧でそれぞれ 30.4 , $28.8,36.7$ および $14.9 \%, 2 / 4$ 肧で $61.2,38.6 .28 .1$ および $18.6 \%$ であった。また，胎仔生存率（生存胎仔 数/移植胚数）は， $1 / 2$ 肧でそれぞれ $25.0 ， 7.7 ， 20.0$ および $4.1 \% ， 2 / 4$ 肧で $28.6 ， 21.2 ， 19.3$ および 7.0 $\%$ で， $1 / 2$ 肧および $2 / 4$ 泼とも胎仔生存率では， 48 時 間 $\rightarrow$ Day 2 の組合わせが最も良好であった。なお，一部 の組合わせにおいて低率ではあるが死亡胎仔が観察され た。

一対の分離胚の移植成績 上述の成績から胎仔生存率 の最も高かった48時間 $\rightarrow$ Day 2 の組合わせで，1/2肧を 対象に一卵性双生仔の作出を試みた。その結果は Table 4 亿示す通りであった。すなわち偽妊娠雌への移植で は, 受容雌26例に52個（26組）の胚を移植した結果， 7 例 $(26.9 \%)$ が分娩に至り, 計 5 匹 $(9.6 \%)$ の産仔が 得られた。このうち 1 組 $(3.8 \%)$ が一塯性双生仔であっ た。一方, 妊娠雌への移植では, 受容雌27例に54個（27 組)の胚を移植した結果, 分離胚由来の産仔を分婏した雌 は16例 $(59.3 \%)$ で, 計 $22 匹(40.7 \%)$ の産仔が得られ た。このうち一卵性双生仔は 6 組 $(22.2 \%)$ であった。

\section{考察}

透明帯を除去したマウス 2 細胞期からの分離胚を体外 で培養した後, 移植によって産仔を得ることは極めて困 難とされており (Fiser and Macherson, 1976; 長嶋ら, 1982；角田・杉江，1984）, これまで Mullen ら (1970) が 1 組の一卵性双生仔を得たという報告があるにすぎな い。しかしながら, 本実験の成績から $1 / 2$ および $2 / 4$ 胚 とも体外培養により高率に胚盤胞へ発生し, さらにそれ らの肧は, 胎仔への発生能力を十分に保持していること が示された。したがって一卵性双生仔作出にあたって は, 泼の分離操作, 体外培養および移植条件などが適切 であれば，分離肧そのものの発生能力については特に問 題にすることはないと思われる。

胚の分離操作に関して, 今回は処理条件の違いによっ て分離成功率や培養成績に大きな差は認められなかった が， 4 細胞期ではすべての胚を 2 割球ずつ均等に分離す ることができず，一部の胚は 1 個と 3 個あるいは 4 個の 割球に分かれる場合があった。しかしながら，ピペッテ ィングによって分離された泼は, マイクロマニピュレー ターによって切断分離された㗏に比較してその後の発生
率が高く（長嶋ら，1982）, 割球への 損傷は極めて少な いと思われた。また，本方法はマイクロマニピュレータ 一のような特別な装置を用いない上に熟練を必要とせ ず，しかも分離に要する時間が短時間で斉むために，一 度に多数の肧を処理することができるといった種々の利 点がある。したがって 2 および 4 細胞期泼のように割球 数の少ない肧を対象とした場合には, 泼の分離法として 有効な方法と考光られる。

次に, 透明带を除去したマウス 2 細胞期の分離胚が体 外培養を経た後, 正常個体へ発生しにくい理由として, 長嶋ら（1984）は初期胚の発生・分化といった観点から 桑実期に異常な割球配置をとることが, 結果的に内部細 胞塊の形成不全を引き起こすためと推察している。ま た，角田・杉江（1984）は 2 細胞期胚を分離後，空の透 明帯に帰納した場合, 帰納しなかった場合に比べて胚盤 胞への発生率が有意に高くなることをみている。これら のことを考兄合わせると，確かに透明帯の有無が胚発生 に重要であるとも思われるが，本実験の成績から判断し た限りでは，分離肧が体外で正常に発生するために必ず しも透明帯が不可欠であるとは考光難い。いずれにして も体外培養に抢ける透明帯の必要性については, 今後よ り詳細な検討が必要であろう。

一方， 2 細胞期胚のような発生初期の胚を体外で培養 した場合, 胚盤胞期での細胞数が生体内で発生した胚に 比べて減少することが知られている。(Wiley et al., 1986; Roblero and Riffo, 1986)。Rands (1985) は2 細胞期胚を分離後, 体外で培養した場合, 胚盤胞期での 細胞数は同一条件で培養された正常胚の約半数となり, 全細胞数に対して内部細胞塊の占める割合も少なくなる ことを指摘している。したがって分離胚から高率に正常 個体を得るためには，今後生体環境により近い条件での 新しい培養法の検討も必要と思われる。また，内部細胞 塊の数と個体への発生能力との関係を明らかにすること は, 一卵性多生仔の作出限界を知る上でも非常に興味深 い問題である。

体外での培養時間と受卵雌の日龄との関係について は, Fisher and Smithberg（1973）が 4 細胞期胚を 2 日 間培養後, 偽妊娠 $1-4$ 日子宮に移植した結果, 2 日目 子宮への移植が最も良好であったと報告している。本実 験においても $1 / 2$ および $2 / 4$ 肧ともに 48 時間培養後, 2 日目子宮へ移植した場合に最も高い胎仔生存率が得ら れ，彼らの報告と同様の傾向を示すものであった。しか しながら, 同一の子宮日齢では培養時間が長い胚を移植 した場合の方が胎仔生存率が低下する傾向にあったこと 
から，体外での培養時間はできる限り短かい方が好まし いと思われる。また, 実際に一甡性双生仔作出にあたっ ては偽妊娠雌に比較して娃娠雌への移植成績が明らかに 良好であったが, Table 3 に示した同一条件（48時間 $\rightarrow$ Day 2) での 偽妊娠雌への移植では成績の向上が認めら れた。このことから移植には偽妊娠と妊娠の違いよりも 子宮内に適当数の胚が存在することが重要と思われた。 したがって偽妊娠雌への移植の場合には, 毛色などマー カーの異なった系統の泼を同時に移植するなどの工夫が 必要と思われるが，実験の効率を考兄ると妊娠雌への移 植が有効と考兄られる。

以上, 比較的簡便なマウスの一卵性双生仔作出法を確 立した。今後作出成功率をより高めるようさらに検討を 加えていきたい。

\section{References}

Brinster RL (1971) In vitro culture of the embryo. in Pathway to Conception (Sherman AI ed.) Charles C. Thomas Publishing Company, Springfield, Illinois. pp 245-277.

Fiser PS, Macpherson JW (1976) Development of embryonic structures from isolated mouse blastomeres. Can J Anim Sci 56: 33-36.

Fisher DL, Smithberg M (1973) Host-transplant relationship of cultured mouse embryos. $J$ Exp. Zool 183: 263-266.

Mullen RJ, Whitten WK, Carter SC (1970) "Annual Report of the Jackson Laboratory" Bar Harbor, Maine. pp 67-68 (from Nagashima et al. 1984).

Nagashima H, Fujikura A, Ogawa S (1982) Studies on the developmental ability and the viability after deep freezing of the blastomeres isolated from 2-cell stage embryos in mice and rabbits. Jpn $J$ Anim Reprod 28: 20-23 (in Japanese).

Nagashima H, Kano Y, Ogawa S (1984) Developmental Biotechnology in Mammals (Meeting of New Approach for Mammalian Embryology ed.)
Softscience, INC. Tokyo. pp 111-124 (in Japanese). Rand GF (1985) Cell allocation in half- and quadruplesized preimplantation mouse embryos. J Exp Zool 236: $67-70$.

Roblero LS, Riffo MD (1986) High potassium concentration improves preimplantation development of mouse embryos in vitro. Fert Steril 45: 412-416.

Tsunoda Y, McLaren A (1983) Effect of various procedures on the viability of mouse embryos containing half the normal number of blastomeres. $J$ Reprod Fert 69: 315-322.

Tsunoda Y, Sugie T (1984) Production of monozygous twin in mice and goats. Jpn J Anim Reprod 30: 18-23 (in Japanese).

Tsunoda Y, Yasui T, Sugie T (1984) Production of monozygotic twins following transfer of separated half embryos in the goat. Jpn J Zootech Sci 55: 643-647 (in Japanese).

Wiley LM, Yamami S, Muyden DV (1986) Effect of potassium concentration, type of protein supplement, and embryo density on mouse preimplantation development in vitro. Fert Steril 45: 111119.

Willadsen SM (1979) A method for culture of micromanipulated sheep embryos and its use to produce monozygotic twins. Nature 277: 298-300.

Willadsen SM (1980) The Viability of early cleavage stages containing half the normal number of blastomeres in the sheep. J Reprod Fert 59: 357362.

Willadsen SM (1981) The developmental capacity of blastomeres from 4- and 8-cell sheep embryos. $J$ Embryol exp Morph 65: 165-172.

Willadsen SM, Polge C (1981) Attempts to produce monozygotic quadruplets in cattle by blastomere separation. Vet Rec 108: 211-213.

Willadsen SM, Lehn-Jensen H, Fehilly CB, Newcomb R (1981) The production of monozygotic twins of preselected parentage by micromanipulation of non-surgically cow embryos. Theriogenology 15: 23-29. 
簡便でかつ効率良く一卵性双生仔を作出する目的で，マウスの 2 および 4 細胞期胚をピペッティン グにより 2 分離し，それぞれの胚の胎仔への発生能について検討した。

その結果, ピペッティングによって分離された胚は, 透明带を除去された状態で体外培養した場合 でも高率に肧盤胞へ発生した。また，肧分離後の培養時間と移植時期（子宮日㱓）との関係において は, $1 / 2$ および $2 / 4$ 肧ともに 48 時間培養後, 偽妊娠 2 日目の子宮角に移植した場合に最も高い胎仔生 存率が得られた。

実際に一卵性双生仔作出にあたっては $1 / 2$ 胚を対象として偽妊娠あるいは妊娠雌の子宮角への移植 を行なった。その結果, 偽妊娠雌への移植では 1 組, 妊娠雌への移植では 6 組, 計 7 組の一卵性双生 仔マウスを得ることができた。

以上のことから透明帯を除去したマウスの 2 および 4 細胞期からの分離胚は, 体外培養を経た後で も胎仔への発生能力を十分保持していること, ならびに 2 細胞期胚からの一卵性双生仔の作出が可能 であることが明らかとなった。 